\section{YOU CAN WRITE FOR:}

ITEMS ARE BELIEVED FREE EXCEPT WHERE PRICE IS LISTED.

Guldelines for Research In Emergency Medical Service Systems, Recently released information related to obtaining grants and contracts in support of the Emergency Medical Services Systerns Act of 1973. For coples write to Bureau of Health Services Research, Attn: EMS, HAA DHEW, Rockville, Md. 20852.

The Personal Dimension of $\mathrm{Pa}$ tieni Care, by Mitchell T. Rabkin M.D Gen. Dir. of Beth Israe Hospital Boston, Mass. Write to Hosp. Research \& Education Association, 5 New England Execu tive Park, Burlington, Ma. 01803 (\$2.00).

FDA Drug Bulletin. To be placed on maiting list: Assistant Direc tor-Medical Communications, Bu reau of Drugs, BD-40, Food and Drug Administration, 5600 Fishers Lane, Rockville, Md. 20852

Epllepsy, a review of last year's literature concerned with epilepsy, including abstracts of 456 references. Write 10 C.N.I.C. University of Nebraska Medica Center, 42nd \& Dewey Ave., Omaha, Neb. 68105, (\$1.50).

Environment News, Monthly publication of Region 1 of the US Environmental Agency For Iree subscription write to Public Allairs Office, U.S. Environmental Protection Agency, Room 2203, J.F.K. Federal Bldg., Bosion, Ma. 02203

Publications List of tree brochures and pamphlets U.S. Environmental Protection Agency, Of lice of Public Affairs, J.F.K Federál Bldg. Boston, Ma. 02203.

DocuBooks - Short booklets de signed to improve physician-patient relationships by presenting in layman's language description of a specific medical procedure and consent forms for patient signing. 100 tilles planned. Titles currently available at $\$ 3.00$ each (reduced prices for quantity purchases): Anesthesia, Angiogram, Appendectomy, Cystoscopy and Urethroscopy, Laminectomy, Myelography, Miniscectomy, PostMortem Examination. Tonslliec tomy and Adenoidectomy, and vasectomy. For further information, write to: HealthCom-Health Communications, Inc. 52 Wes Kellogg Blvd., St. Paul, Minn. 55102 .

\title{
Journal Editorial Board Completed
}

The American Journal of Law \& Medicine - Editorial Board Completed for 1974

John A. Norris, J.D., M.B.A., Editor-in-Chiel of the American Journal of Law Medicine, announces that the Journal's Board of Editors is now completed Supplementing the Editorial Board positions previously listed in Med. icolegal News, Vol 2 No 3 , page 8 are: Neil L. Chayet, J.D., noted Consultant in Health Law; Bernard D. Hirsh, J.D., General Counsel of the American Medical Assoclation; John F. Lombard, J.D., Health Law Consultant and Proressor at Suffolk University Law School; Kevin M. Mclntyre, M.D. J.D., Cardiologist at the West Roxbury Veterans Administration Hospital in Boston and Harvard Medical School; and the Honorable Max Rosenn, Justice, the United States Court of Appeals, Wilkes Barre. Pa. James Holzar J.D. has been appointed as Busi ness Manager and Deanna $E$. Sagall Administrative Manager.
Announcements of the formation of the American Journal of Law \& Medicine have been sent to leading U.S. and Canadian periodicals, professional organization's, and to the Deans of U.S and Canadian medical, law and dental schools and to the medical, legal and insurance book publishers. Manuscripts and books for review purposes should be directed to ASLM Headquarters.

Target date lor the inaugural issue is February 1975, and under ASLM new dues structure (see below) all 1975 members of the American Society of Law \& Medicine, lnc. will receive a free subscription to this promising entrance of ASLM into the publication of a much-needed journal which will feature scholarly indepth articles and reviews of books on topics reiated to the interdisciplinary study of law and medicine of interest and practical value to a large and diverse audience.

\section{NOTICE TO ASLM MEMBERS:}

Tc permit free distribution of ASLN's forincoming biannual American Joumal of Law \& Medjcine :C all ASLM members and because of mounting clerical costs. the Executive Committee of the American Society of Lavi \& Medicine, inc. has set the following dues structure for the calendar year ending December 31, 1975: Personai membershios: - $\$ 25.00$ Studen: memberships: - $\$ 5.00$ Corporatelinstitution sporisor memberships: - $\$ 150.00$ inciudes listing of 10 persons vith unlimited additional listings over 10 at $\$ \$ 5$ each.

All ASLM memberships include withoui acditionai charge:

- Annual subscription to Medicolegal News

- Annual subscriotion to American Joumal of Law \& Medicine

- Reduced membership recistia tion fees to all AiSM progiams, seminars, symposia and dinne meetings

- Free listing privileges for the ASLM Speaker-instructor Bureau
- Free Counseling savices from ine ASLM Medicolegal Careei Givioance Center

- Regular distributicn of ASLM notices. news and announce ments

- Free or special membersnip reductions for future ASLM services and pubijcaticns.

Naw membersnip appicátions ieceives after October 15, 1974 a: the above dues assessment will automatically be extended withou: adcitional charge through December $3 i, 1975$

New applications received after Juiy i, 1975 may at the applicant's opticn be at $70 \%$ dues assessmient to include the last hatf-year 1975.

The American Society of Law \& Medicine, inc, has been Jesigna:ed a nonprofit. tax exerro: organization by the Interna! Revente Service ('RS ruling as 501 (c) (3) and 509 (2) (a). ASLM memicership charges are tax seductible as a business expense or as a chasitabie coritribution. 